\title{
Agronomic Efficiency of Biosolid as Source of Nitrogen to Banana Plants
}

\author{
Luiz Antonio Junqueira Teixeira, ${ }^{1}$ Ronaldo Severiano Berton, ${ }^{1}$ Aline Reneé Coscione, ${ }^{1}$ \\ Luis Alberto Saes, ${ }^{2}$ and Marcio Koiti Chiba ${ }^{1}$
}

${ }^{1}$ Soils and Environmental Resources Center, Agronomic Institute (IAC/APTA), Avenida Barao de Itapura, 1481 Botafogo, 13020902 Campinas, SP, Brazil

${ }^{2}$ Ribeira Valley Regional Pole (DDD/APTA), Road BR116, km 460, P.O. Box 122, 11900000 Registro, SP, Brazil

Correspondence should be addressed to Marcio Koiti Chiba; mkchiba@iac.sp.gov.br

Received 19 August 2014; Revised 1 December 2014; Accepted 17 December 2014

Academic Editor: Alejandro Valdecantos

Copyright (C) 2015 Luiz Antonio Junqueira Teixeira et al. This is an open access article distributed under the Creative Commons Attribution License, which permits unrestricted use, distribution, and reproduction in any medium, provided the original work is properly cited.

\begin{abstract}
Sewage sludge (SS) or biosolid has been studied as source of nutrient for several different plant species. It also contributes to soil fertility recycling organic matter and plant nutrients. This followup work examines a three-year (2001-2004) field experiment designed to evaluate the response of banana plants (Cavendish subgroup) to the application of biosolid as source of nitrogen. The treatments consisted of control (mineral PK, no N), three rates of sludge, and two rates of mineral NPK fertilizer. Plant and soil $\mathrm{N}$ concentration, fruit yield, plant height, stem diameter, and foliar endurance index were measured. Fruit yield with mineral fertilization or sludge applications did not differ statistically $(P>0.05)$. Application of biosolid resulted in statistically significant higher agronomic efficiency $(P<0.05)$ in comparison to mineral fertilizers. The concentration of soil mineral nitrogen increased using mineral fertilizer or sludge until $0.80 \mathrm{~m}$ after three years of application. The effect of the source of $\mathrm{N}$ was smaller than the effect of the rate. Biosolid can be used as source of $\mathrm{N}$ for banana growers.
\end{abstract}

\section{Introduction}

Among the alternatives to dispose biosolid, recycling on agricultural land offers economic and environmental benefits. The key concept of land application of biosolid [1-3] is the return of organic matter and plant nutrients removed by crops. Some researchers have reported that biosolid application also improves soil physical properties [4-6]. Biosolids were effective to substituted mineral fertilizers as source of nitrogen $(\mathrm{N})$ for ryegrass [7], sugarcane $[1,2,8]$, sunflower $[9]$, and maize $[10,11]$. In all of these, there were no indications of environmental hazards due to biosolid addition in soils. In Brazil, as in many other places, there is a specific regulation about the application of biosolids in agricultural soils [12] and for agronomic purposes, the sludge rate must be calculated by using the sludge's $\mathrm{N}$ mineralization rate $\left(\mathrm{N}_{\mathrm{MR}}\right)$ and the plant requirement.

Andrade et al. [11] pointed out that the successive application of biosolid can cause an increase of the potential mineralizable $\mathrm{N}$, underestimating the soil capacity of providing N. Situations like that could represent environmental risks as the gradual increase of soil capacity to supply $\mathrm{N}$ should be coupled to a decrease in the rates of sludge applied as fertilizer preventing nitrate leaching $[13,14]$ and soil $\mathrm{N}_{2} \mathrm{O}$ emissions $[15,16]$.

Besides the environmental concern, the use of biosolid as source of $\mathrm{N}$ for banana could be beneficial as the plant grows fast and requires high levels of nutrients to produce biomass and fruits. Literature review indicates that plant of banana producing around $50 \mathrm{t}$ fruits $\mathrm{ha}^{-1} \mathrm{year}^{-1}$ demands from 198 to $388 \mathrm{~kg} \mathrm{ha}^{-1}$ of N and 29 to $52 \mathrm{~kg} \mathrm{ha}^{-1}$ of P [17]. Although the biosolid, as source of plant nutrients, has been evaluated for other plant species, there is a lack of knowledge about crops highly nutrient demanding.

In this study, we hypothesized that the biosolid was similar to mineral $\mathrm{N}$ fertilizer to supply the required nutrients to banana plants. The objectives of this work were to evaluate the banana response to the application of biosolid as source 
of $\mathrm{N}$ in terms of fruit yield, $\mathrm{N}$ uptake, and agronomic effectiveness of $\mathrm{N}$ usage.

\section{Materials and Methods}

2.1. Site Description. The experiment described in this paper is complementary to that reported by Teixeira et al. [18] which discussed only soil parameter modifications by sludge application. Here, fruit yield from three cropping cycles, the agronomic efficiency use of $\mathrm{N}$ from sludge, and the concentration of soil nitrogen $\left(\mathrm{N}_{-} \mathrm{NO}_{3}{ }^{-}\right.$and $\left.\mathrm{N}-\mathrm{NH}_{4}{ }^{+}\right)$were presented. The experiment was carried out between September 2001 and December 2004 at the city of PariqueraAçu, state of Sao Paulo, Brazil $\left(24^{\circ} 39^{\prime} \mathrm{S} ; 47^{\circ} 55^{\prime} \mathrm{W}\right)$. This region cropped around 38,500 hectares of land with banana, representing $70 \%$ of the total area planted with this specie in the state of Sao Paulo. Historical climatic records from $01 / 10 / 1992$ to $31 / 12 / 2004$ showed that the monthly averaged minimum/maximum air temperature ranged from $23.2^{\circ} \mathrm{C}$ (July) to $31.1^{\circ} \mathrm{C}$ (February); monthly rainfall averaged from $54.7 \mathrm{~mm}$ (August) to $298.6 \mathrm{~mm}$ (January). Climate data of experimental period and most relevant management practices performed during cropping period were presented in Figure 1.

The soil was classified by Sakai and Lepsch [19] as a clayey texture (34.0\% of clay, $0.9 \%$ of silt and $57.0 \%$ of sand) A horizon alic Yellow Oxisol (Pariquera Unit-I). Before trial installation, soil chemical characteristics were evaluated according Raij et al. [20] in composite samples $(n=6)$ collected from depths of $0-0.20$ and $0.20-0.40 \mathrm{~m}$ resulting in values of $\mathrm{pH} \mathrm{CaCl}_{2}=4$ and 4 ; soil organic carbon $=23 \mathrm{~g} \mathrm{dm}^{-3}$ and $18 \mathrm{~g} \mathrm{dm}^{-3} ; \mathrm{K}^{+}=1.6 \mathrm{mmol}_{(+)} \mathrm{dm}^{-3}$ and $1.2 \mathrm{mmol}_{(+)} \mathrm{dm}^{-3}$; $\mathrm{Ca}^{2+}=8 \mathrm{mmol}_{(+)} \mathrm{dm}^{-3}$ and $7 \mathrm{mmol}_{(+)} \mathrm{dm}^{-3} ; \mathrm{Mg}^{2+}=2$ $\mathrm{mmol}_{(+)} \mathrm{dm}^{-3}$ and $2 \mathrm{mmol}_{(+)} \mathrm{dm}^{-3} ; \mathrm{H}+\mathrm{Al}^{+}=90$ $\operatorname{mmol}_{(+)} \mathrm{dm}^{-3}$ and $92 \mathrm{mmol}_{(+)} \mathrm{dm}^{-3}$; and base saturation index as $(\mathrm{K}+\mathrm{Ca}+\mathrm{Mg}) / \mathrm{CEC}=12.3 \%$ and $10 \%$, respectively. Based in this data, soil received dolomitic limestone (effective calcium carbonate equivalent $=67 \%$ ) in order to increase the base saturation index $(\mathrm{V})$ to $60 \%$. Soil preparation consisted of disc plowing, harrowing and furrowing until the depth of $0.35 \mathrm{~m}$.

2.2. Sludge and Application Rates. Biosolid was produced by the sewage treatment plant of the city of Mongagua, located $170 \mathrm{~km}$ far north of the experimental site. This plant processes municipal sewage by using the method of Sequencing Batch Reactor (SBR) or "Fill and Draw System" with hydraulic retention time of around 6-7 hours. Selected characteristics of the sludge, on different years, are in Table 1 . Sludge available $\mathrm{N}$ was quantified according CETESB [21]. Organic carbon (OC) and nitrogen forms (Kjeldahl-N, $\mathrm{NH}_{4}-\mathrm{N},\left(\mathrm{NO}_{3}+\mathrm{NO}_{2}\right)-\mathrm{N}$ ) were determined according Raij et al. [20]. Nutrients and heavy metals were extracted according to the 3051 US-EPA method [22] and quantified by inductively coupled plasma atomic emission spectroscopy (ICP-AES). Sludge $\mathrm{pH}$ was determined at $1: 10$ water extract $(\mathrm{m} / \mathrm{v})$; humidity and volatile solids (VS) by mass loss at $60^{\circ} \mathrm{C}$ and $500^{\circ} \mathrm{C}$, respectively.

Sludge rate was calculated to match the theoretical banana requirement for nitrogen. In the state of Sao Paulo, $\mathrm{N}$ fertilizer recommendation to produce $50-60 \mathrm{tha}^{-1}$ of fruits is $430 \mathrm{~kg} \mathrm{~N} \mathrm{ha}^{-1}$ [23]. Therefore, rates equivalent to $0.5,1.0$ and 2 times of the mentioned $\mathrm{N}$ rate were applied. For first growing season, sludge rates were equal to $T_{L 1}=219 \mathrm{~kg} \mathrm{ha}^{-1} \mathrm{~N} ; T_{L 2}=$ $400 \mathrm{~kg} \mathrm{ha}^{-1} \mathrm{~N}$ and $T_{L 3}=870 \mathrm{~kg} \mathrm{ha}^{-1} \mathrm{~N}$ (Table 2). For the subsequent two growing seasons the nitrogen rate were reduced by half (i.e., $T_{L 1}=100 \mathrm{~kg} \mathrm{ha}^{-1} \mathrm{~N} ; T_{L 2}=200 \mathrm{~kg} \mathrm{ha}^{-1} \mathrm{~N}$ and $T_{L 3}=400 \mathrm{~kg} \mathrm{ha}^{-1} \mathrm{~N}$ ) in all treatments (Table 2). This modification on sludge rate was necessary because, in an unexpected way, fruit production reached $50-60 \mathrm{tha}^{-1}$ in the first growing season. As the nitrogen mineralization rate of the biosolid was determined as $30 \%$ we supposed the full response of fruit yield would occur only in the second or third season, when most of the $\mathrm{N}$ was mineralized. Therefore, facing to the high productivity in the first cropping season and to prevent plant toxicity or environmental concerns we adopted a reduced rate of the sludge. This occurred because for normal agricultural practices in Sao Paulo State, the recommendation for $\mathrm{N}$ application is based on expected productivity.

Sewage sludge rate $\left(\mathrm{SS}_{R}\right)$ was calculated considering the amount of $\mathrm{N}$ required by the plants $\left(\mathrm{N}_{\mathrm{RP}}\right)$, the content $\mathrm{N}$ available on the residue $\left(\mathrm{SS}_{\mathrm{N}}\right)$ (Table 1 ) by using (1).

$$
\mathrm{SS}_{\mathrm{R}}, \mathrm{kg} \mathrm{ha}^{-1}=\mathrm{N}_{\mathrm{RP}} \times \mathrm{SS}_{\mathrm{N}} .
$$

The nitrogen mineralization rate $\left(\mathrm{N}_{\mathrm{MR}}\right)$ was determined in a laboratorial trial (data not shown) and was equal to $30 \%$ of total N. For planting (2) and growing seasons 2 and 3 (3) amendments two different equations to estimate $\mathrm{SS}_{\mathrm{N}}$ were used:

$$
\begin{aligned}
\mathrm{SS}_{\mathrm{N}}= & \left(\frac{\mathrm{N}_{\mathrm{MR}}}{100}\right) \times\left(\mathrm{Kjeldahl}_{\mathrm{N}}-\mathrm{NH}_{3}-\mathrm{N}\right) \\
& +\mathrm{NH}_{3}-\mathrm{N}+\mathrm{NO}_{3}{ }^{-}-\mathrm{N}+\mathrm{NO}_{2}^{-}-\mathrm{N} \\
\mathrm{SS}_{\mathrm{N}}= & \left(\frac{\mathrm{N}_{\mathrm{MR}}}{100}\right) \times\left(\mathrm{Kjeldahl}_{\mathrm{N}}-\mathrm{NH}_{3}-\mathrm{N}\right) \\
& +0.5 \times\left[\mathrm{NH}_{3}-\mathrm{N}+\mathrm{NO}_{3}^{-}-\mathrm{N}+\mathrm{NO}_{2}{ }^{-}-\mathrm{N}\right],
\end{aligned}
$$

where Kjeldahl- $\mathrm{N}=$ total nitrogen $\left(\mathrm{mg} \mathrm{kg}^{-1}\right) ; \mathrm{NH}_{4}{ }^{+}-\mathrm{N}=$ nitrogen as ammonia $\left(\mathrm{mg} \mathrm{kg}^{-1}\right) ; \mathrm{NO}_{3}^{-}-\mathrm{N}=$ nitrogen as nitrate $\left(\mathrm{mg} \mathrm{kg}^{-1}\right) ; \mathrm{NO}_{2}^{-}-\mathrm{N}=$ nitrogen as nitrite $\left(\mathrm{mg} \mathrm{kg}^{-1}\right)$.

This was necessary because in 2002 and in 2003, biosolid was manually side-dressed without incorporation into the soil, over a one meter-wide strip alongside the plant rows.

2.3. Orchard Planting, Management and Sampling. Experiment consisted of plots with $100 \mathrm{~m}^{2}(10 \times 10 \mathrm{~m})$ distributed in a complete randomized design, with five replicates $(n=5)$. Twenty banana plantlets per plot were planted $(2.5 \times 2.0 \mathrm{~m}$ spacing) by using in vitro micropropagated Grand Naine cultivar (AAA group, Cavendish subgroup) material. By the time of the orchard establishment the plantlets presented, in average $(n=50), 4.4$ leaves and $0.221 \mathrm{~m}$ height.

In 2001, biosolid was applied into the furrows, between the planting holes, and carefully incorporated to the soil. Fertilizer phosphorus was applied in all plots, twice during 
TABLE 1: Chemical composition of the municipal biosolid applied to a banana plantation in the city of Pariquera-Açu as source of nitrogen over three crop seasons.

\begin{tabular}{|c|c|c|c|c|c|c|c|c|c|}
\hline \multirow{2}{*}{ Parameter } & \multirow{2}{*}{ Unit } & \multicolumn{3}{|c|}{ Growing season } & \multirow{2}{*}{ Parameter } & \multirow{2}{*}{ Unit } & \multicolumn{3}{|c|}{ Growing season } \\
\hline & & 2001 & 2002 & 2003 & & & 2001 & 2002 & 2003 \\
\hline $\mathrm{P}$ & $\mathrm{g} \mathrm{kg}^{-1 *}$ & 15.4 & 11.6 & 8.7 & OC & $\mathrm{g} \mathrm{kg}^{-1 *}$ & 222.7 & 302.8 & 172.4 \\
\hline $\mathrm{K}$ & $\mathrm{g} \mathrm{kg}^{-1 *}$ & 0.9 & 0.8 & 1.0 & $\mathrm{pH}$ & & 9.9 & 12.7 & 12.6 \\
\hline $\mathrm{Na}$ & $\mathrm{g} \mathrm{kg}^{-1 *}$ & 0.6 & 0.8 & 0.4 & Humidity & $\%(\mathrm{~m} / \mathrm{m})$ & 71.2 & 64.3 & 62.9 \\
\hline As & $m g \mathrm{~kg}^{-1 *}$ & $<0.1$ & $<0.1$ & $<0.1$ & Volatile solids & $\%(\mathrm{~m} / \mathrm{m})^{*}$ & 52.5 & 43.9 & 35.1 \\
\hline $\mathrm{Cd}$ & $\mathrm{mg} \mathrm{kg}^{-1 *}$ & 10.3 & 1.2 & 0.5 & Kjeldahl-N & $\mathrm{g} \mathrm{kg}^{-1 *}$ & 32.0 & 31.1 & 21.5 \\
\hline $\mathrm{Pb}$ & $\mathrm{mg} \mathrm{kg}^{-1 *}$ & 83.6 & 115.6 & 21.0 & $\mathrm{NH}_{4}-\mathrm{N}$ & $\mathrm{mg} \mathrm{kg}^{-1 * *}$ & 1941.5 & 806.7 & 591 \\
\hline $\mathrm{Cu}$ & $\mathrm{mg} \mathrm{kg}^{-1 *}$ & 139.6 & 115.6 & 67.2 & $\left(\mathrm{NO}_{3}+\mathrm{NO}_{2}\right)-\mathrm{N}$ & $\mathrm{mg} \mathrm{kg}^{-1 * *}$ & 47.1 & 42.0 & 33.5 \\
\hline $\mathrm{Cr}$ & $\mathrm{mg} \mathrm{kg}^{-1 *}$ & 43.8 & 19.3 & 14.5 & S & $\mathrm{g} \mathrm{kg}^{-1 *}$ & 7.7 & 7.0 & 6.74 \\
\hline $\mathrm{Hg}$ & $\mathrm{mg} \mathrm{kg}^{-1 *}$ & ND & ND & ND & Mn & $\mathrm{mg} \mathrm{kg}^{-1 *}$ & 778.5 & 539.4 & 342.8 \\
\hline Mo & $\mathrm{mg} \mathrm{kg}^{-1 *}$ & ND & ND & ND & $\mathrm{Fe}$ & $\mathrm{g} \mathrm{kg}^{-1 *}$ & 106.4 & 50.9 & 54.7 \\
\hline $\mathrm{Ni}$ & $\mathrm{mg} \mathrm{kg}^{-1 *}$ & 22.2 & 12.7 & 9.9 & $\mathrm{Mg}$ & $\mathrm{g} \mathrm{kg}^{-1 *}$ & 5.9 & 4.8 & 3.8 \\
\hline $\mathrm{Se}$ & $\mathrm{mg} \mathrm{kg}^{-1 *}$ & ND & ND & ND & $\mathrm{Al}$ & $\mathrm{g} \mathrm{kg}^{-1 *}$ & 7.0 & 6.7 & 5.5 \\
\hline $\mathrm{Zn}$ & $\mathrm{mg} \mathrm{kg}^{-1 *}$ & 573.4 & 449.8 & 281.6 & $\mathrm{Ca}$ & $\mathrm{g} \mathrm{kg}^{-1 *}$ & 173.6 & 359.6 & 193.7 \\
\hline B & $\mathrm{mg} \mathrm{kg}^{-1 *}$ & 22.9 & 13.9 & 7.4 & Available-N & $\mathrm{g} \mathrm{kg}^{-1 * *}$ & 2.96 & 3.41 & 2.32 \\
\hline
\end{tabular}

${ }^{*}$ On dry matter basis; ${ }^{* *}$ determined on biosolid with natural moisture content.

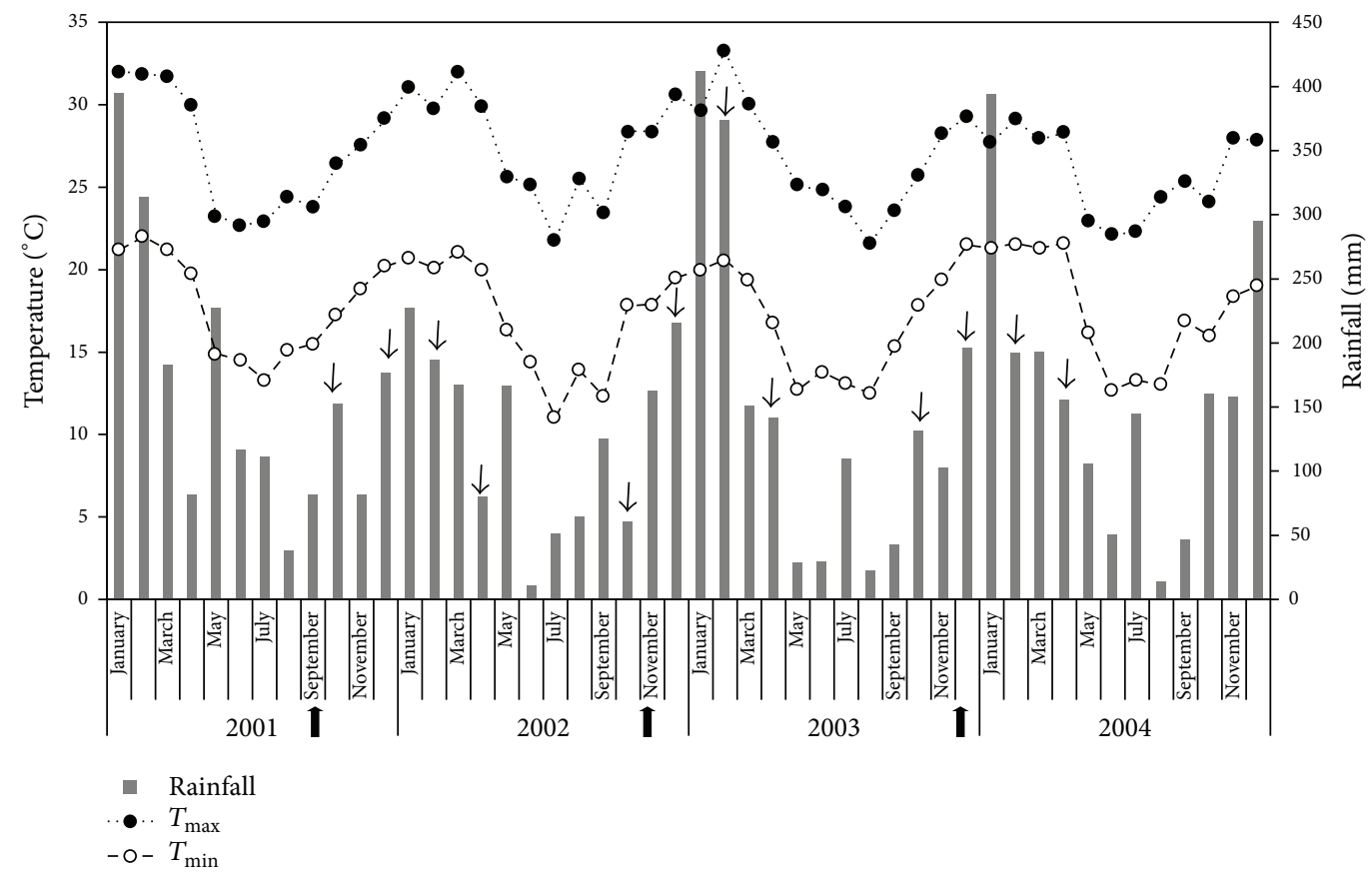

FIGURE 1: Climatic parameters over the period of 2001-2004 in the city of Pariquera-Açu at Sao Paulo State, Brazil. Upward fulfilled black arrows indicate the sludge application dates. Mineral fertilizer application was split in four events (25\% each) within the same crop season and was represented by the downward arrows.

the trial: $150 \mathrm{~kg} \mathrm{ha}^{-1}$ of $\mathrm{P}_{2} \mathrm{O}_{5}$, into the furrows by the planting (in 2001) and $200 \mathrm{~kg} \mathrm{ha}^{-1}$ of $\mathrm{P}_{2} \mathrm{O}_{5}$ was broadcasted on soil surface in 2003. The source of $\mathrm{P}$ was phosphate $\left(41 \% \mathrm{P}_{2} \mathrm{O}_{5}\right)$. Potassium was yearly applied at a rate of $342 \mathrm{~kg} \mathrm{ha}^{-1}$ year $^{-1}$ of $\mathrm{K}$ as $\mathrm{KCl}$, and nitrogen as $\mathrm{NH}_{4} \mathrm{NO}_{3}(32 \% \mathrm{~N})$ according to each treatment (Table 2). Fertilization with potassium and nitrogen was split in four events during the crop cycle (Figure 1).

Due to its own biological characteristics, as banana plant grows new suckers from its rhizome comes out. The management of the plants consisted of pruning and keeping a clump formed by three plants (parent plant, first and second 


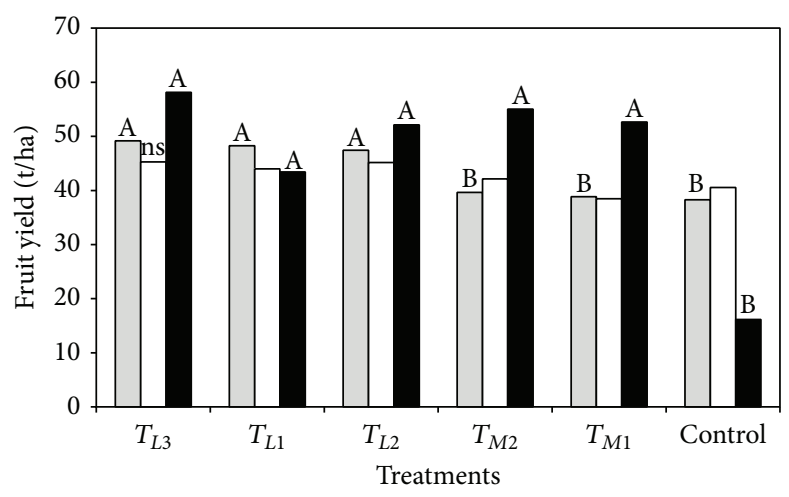

$\square$ Crop season 1

$\square$ Crop season 2

- Crop season 3

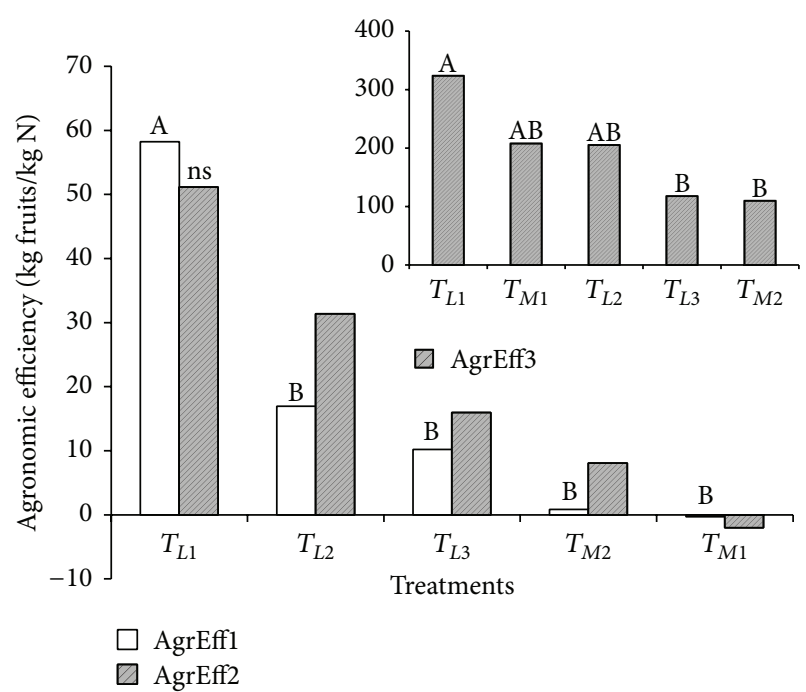

(b)

Figure 2: Biosolid and mineral fertilizer application on fruit yield (a) and agronomic efficiency index (b). Columns, within the same crop season, labelled with different letters on top are significantly different $(P<0.05)$. ns $=$ not significant $(P>0.05)$. In (b) observe the difference of scale on $y$-axis. $T_{L 1}, T_{L 2}$, and $T_{L 3}$ correspond to the equivalent amount of approximately 100, 200, and $400 \mathrm{~kg} \mathrm{ha}^{-1} \mathrm{year}^{-1}$ of $\mathrm{N}$ applied as SS. $T_{M 1}$ and $T_{M 2}$ were equivalent to the application of 200 and $400 \mathrm{~kg} \mathrm{ha}^{-1}$ year $^{-1}$ of N as NPK mineral fertilizer.

suckers). Only the parental plant of each plot was used to record fruit yield, plant height, pseudo-stem diameter and to collect leaf samples. Soil sampling was done yearly, after the fruit harvesting, in 2002, 2003, and 2004. In 2002 and 2003 soil samples were taken from depths of $0-0.2,0.2-0.4,0.4-$ $0.6 \mathrm{~m}$. In 2004 the layer of $0.60-0.80 \mathrm{~m}$ was also collected. Fresh soil samples were analyzed for $\mathrm{N}_{-} \mathrm{NO}_{3}{ }^{-}$and $\mathrm{N}-\mathrm{NH}_{4}{ }^{+}$ after extraction with $2 \mathrm{~mol} \mathrm{~L}^{-1} \mathrm{KCl}$ solution according to Raij et al. [20]. Fertility parameters were evaluated in $2 \mathrm{~mm}$ sieved air-dried soil samples and processed according Raij et al. [20].

To evaluate the effect of sludge and fertilizer applications on soil organic matter variations from the initial condition, before the application of sludge or fertilizer, were calculated every year as $\Delta_{\mathrm{SOM}}=S O M_{\text {year }}-\mathrm{SOM}_{\text {initial }}$. Thus, a positive $\Delta_{\text {SOM }}$ indicates accumulation of carbon for a specific treatment, depth and time.

Plant nutrition was evaluated by using the chemical leaf tissue analysis [24] prepared according to procedures described by Bataglia et al. [25].

The agronomic efficiency index (AgrEff) was calculated according to (4):

$$
\operatorname{AgrEff}=\frac{\left(Y_{\text {fert }}-Y_{\text {unfert }}\right)}{Q_{\mathrm{NA}}},
$$

where AgrEff = agronomic efficiency index in $\mathrm{kg}_{\text {fruits }} \mathrm{kg}^{-1}$ of $\mathrm{N}$ applied; $Y_{\text {fert }}=$ Production of harvested biomass (Fruits + peduncle) with $\mathrm{N}, \mathrm{kg} \mathrm{ha}^{-1} ; Y_{\text {unfert }}=$ Yield without $\mathrm{N}, \mathrm{kg} \mathrm{ha}^{-1}$ (Control); $Q_{\mathrm{NA}}=$ Amount of $\mathrm{N}$ applied, $\mathrm{kg} \mathrm{ha}^{-1}$.

Pseudo-stem diameter was measured at the height of $0.30 \mathrm{~m}$ from the soil surface and the plant height was measured from soil surface to the insertion point of youngest leaf. In addition, the leaf endurance index (LEI), which is the number of active leaves at the harvesting divided by the number of active leaves at bunch emission, was calculated. " $L E I$ " represents the maintenance of active leaves by plants and the practical experience of the researches involved in this paper has showed that there was a direct and positive relationship between LEI and yield.

2.4. Statistical Calculations and Data Analysis. Data were analyzed using analysis of variance (ANOVA) for randomized complete block designs to test the effect of treatments. Means were compared by using Tukey's HSD test. All calculations considered the level of significance of $P=0.05$ and were performed in Minitab v.16.

\section{Results and Discussion}

As said at the beginning, this paper continues to explore the experiment previously reported by Teixeira et al. [18]. Also, data of first fruit yield became available after the publication of the soil parameters [18], allowing to consider that these was partially resulted from the sludge application in 2001. In this way, some information about the soil from the first growing season already presented by Teixeira et al. [18] is been showed again to facilitate discussions.

3.1. Fruit Productivity and Agronomic Efficiency. In the first growing season, treatments that received sludge produced higher amounts of fruits (Figure 2(a)). Unlikely, plants cultivated with the similar $\mathrm{N}$ rate, but applied as mineral fertilizer $\left(T_{M 2}\right)$, did not respond in the same way (Figure 2(a)). Besides the addition of sludge increases the availability of nitrogen and phosphorus other factors should be improving the biomass production. 


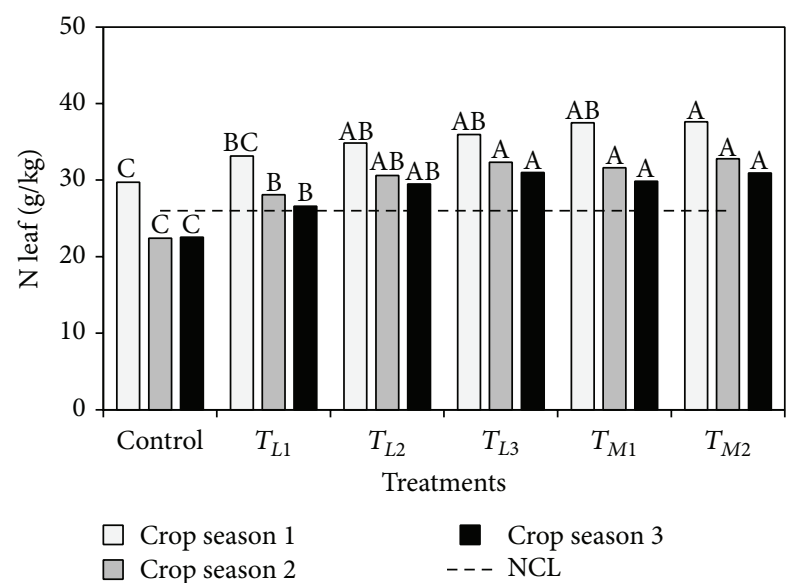

(a)

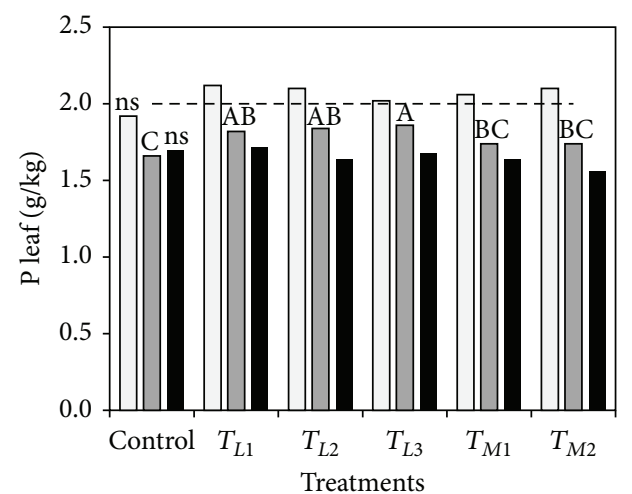

$\square$ Crop season 1
$\square$ Crop season 2

(b)

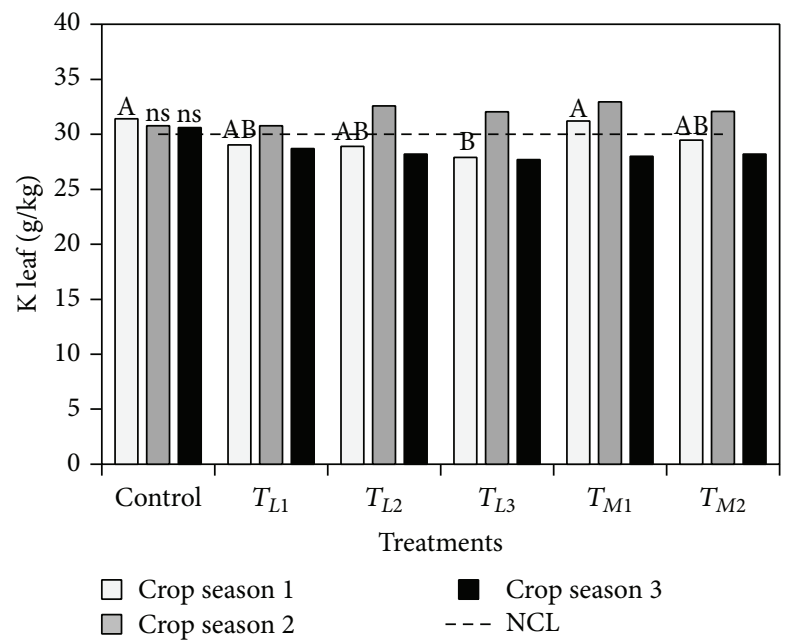

(c)

Figure 3: Nitrogen (a), phosphorus (b), and potassium (c) concentrations in banana leaves with sewage-sludge $\left(T_{L}\right)$ and mineral fertilizer $\left(T_{M}\right)$. Columns with the same letter on top, within crop season, indicate that the mean does not differ by Tukey's HSD test $(P>0.05)$. ns $=$ ANOVA $F$ test is not significant for treatments effects $(P>0.05)$. Dashed line represents the nutrient critical level (NCL) according to Raij et al. [37].

The precise contribution of sludge is difficult to measure comparing the yield from Control to amended treatments. Control also received $\mathrm{P}$ and $\mathrm{K}$; thus part of the variation observed was caused by the supply of N. Besides, yield in first two growing seasons did not differentiated among treatments with biosolid rates.

The highest yield obtained with sludge amendment can be due to double effect of the organic material supplying nutrients and improving soil physical parameters as well $[4$, 5]. Unfortunately, soil physical properties were not measured in this work and more considerations cannot be made.

Absence of plant response in mineral fertilized treatments in comparison to the Control can be partially input to natural soil fertility. Although $\mathrm{N}$ supply is used as indicator to sludge rate application, there was no agreement about soil $\mathrm{N}$ evaluation. More about soil $\mathrm{N}$ is shown in Section 3.2 of this paper.

Fruit production in the Control treatment without $\mathrm{N}$ at similar levels to plants amended with mineral fertilizer $\left(T_{M 1}\right.$ and $T_{M 2}$ ) reinforces this statement.
The data from the third growing season (AgrEff3) were considered without influence of the natural soil fertility and analyzed with more detail (Figure 2(b)). It reflected the data of fruit yield but showed that the application of the smallest rate of sludge $\left(T_{L 1}\right)$ was the most effective then the mineral amendment. This reinforces the observation that biosolid is not a pure source of nutrients but also affects other soil parameters resulting in a more efficient use of them.

Furthermore, in general, biosolid increased the AgrEff within growing seasons, but the ratio of AgrEff between biosolid to fertilizer (AgEff_ $T_{L} /$ AgEff_$\left._{-} T_{M}\right)$ diminished from 103.5 (growing season 1) to 10.77 (growing season 2) and 1.36 (growing season 3). Probably the biosolid re-application is increasing the amount of $\mathrm{N}$ potentially mineralizable and therefore, reducing the proportion of fruits per kilogram of applied $\mathrm{N}$ as postulated by others $[11,26]$.

3.2. Plant Nutrition. Foliar $\mathrm{N}$ and $\mathrm{P}$ contents agreed with the yield data (Figure 3). For the three crop cycles the $\mathrm{N}$ concentrations for Control treatment were lower than the observed 
TABLE 2: Description of treatment and additional information.

\begin{tabular}{|c|c|c|c|}
\hline Treatment & Fertilization & $\begin{array}{c}\text { Biosolid rate } \\
\text { tha }^{-1} \text { (dry base) }\end{array}$ & $\begin{array}{c}\text { Nitrogen } \\
\mathrm{kgha}^{-1}\end{array}$ \\
\hline & 2001 & & \\
\hline Control & $\begin{array}{c}\text { No } N+\text { mineral } \\
\text { fertilization }(P+K)\end{array}$ & - & - \\
\hline$T_{L 1}$ & Biosolid rate $1+\mathrm{K}$ & 21.3 & 219 \\
\hline$T_{L 2}$ & Biosolid rate $2+\mathrm{K}$ & 42.6 & 435 \\
\hline$T_{L 3}$ & Biosolid rate $3+\mathrm{K}$ & 85.2 & 870 \\
\hline$T_{M 1}$ & Mineral $N($ rate 1$)+P+K$ & - & 400 \\
\hline \multirow[t]{2}{*}{$T_{M 2}$} & Mineral $\mathrm{N}($ rate 2$)+\mathrm{P}+\mathrm{K}$ & - & 800 \\
\hline & 2002 & & \\
\hline Control & $\begin{array}{c}\text { No } N+\text { mineral } \\
\text { fertilization }(P+K)\end{array}$ & - & - \\
\hline$T_{L 1}$ & Biosolid rate $1+\mathrm{K}$ & 10.7 & 100 \\
\hline$T_{L 2}$ & Biosolid rate $2+\mathrm{K}$ & 21.4 & 200 \\
\hline$T_{L 3}$ & Biosolid rate $3+\mathrm{K}$ & 42.8 & 400 \\
\hline$T_{M 1}$ & Mineral N (rate 1$)+\mathrm{P}+\mathrm{K}$ & - & 200 \\
\hline$T_{M 2}$ & Mineral $\mathrm{N}($ rate 2$)+\mathrm{P}+\mathrm{K}$ & - & 400 \\
\hline & 2003 & & \\
\hline Control & $\begin{array}{c}\text { No } N+\text { mineral } \\
\text { fertilization }(P+K)\end{array}$ & - & - \\
\hline$T_{L 1}$ & Biosolid rate $1+\mathrm{K}$ & 13.9 & 100 \\
\hline$T_{L 2}$ & Biosolid rate $2+\mathrm{K}$ & 27.8 & 200 \\
\hline$T_{L 3}$ & Biosolid rate $3+\mathrm{K}$ & 55.5 & 400 \\
\hline$T_{M 1}$ & Mineral $\mathrm{N}($ rate 1$)+\mathrm{P}+\mathrm{K}$ & - & 200 \\
\hline$T_{M 2}$ & Mineral $\mathrm{N}($ rate 2$)+\mathrm{P}+\mathrm{K}$ & - & 400 \\
\hline
\end{tabular}

in $T_{L}$ and $T_{M}$ treatments. In terms of foliar phosphorus concentration, biosolid presented similar effectiveness than mineral fertilizer amendments (Figure 3(b)) although no difference between $T_{L 1}$ and $T_{L 3}$ rates were observed.

These results agree with the observed for other species in which a significant amount of $\mathrm{P}$ was released by the biosolid $[2,27-32]$. Also it is important consider that the establishment of biosolid application rate based on $\mathrm{N}$ availability, in this case, resulted in high amounts of $\mathrm{P}$ being added to soil ranging from $1278 \mathrm{~kg} \mathrm{ha}^{-1}\left(T_{L 3}\right.$-in 2001) to $121 \mathrm{~kg} \mathrm{ha}^{-1}$ ( $T_{L 1}$-in 2003).

Statistical significant effect of treatments on potassium foliar concentrations was found only in the data of the first growing season (Figure 3(c)). Some can highlight the difference of $\mathrm{K}$ content between $T_{L 3}$ and $T_{M 1}$ but is important to observe that the treatment $T_{M 2}$ presented similar values. Because potassium was applied to all treatments and as there was no consistent alterations of foliar concentration with biosolid rates increase, further considerations about this nutrient are difficult to be made.

These results support the conclusion of Teixeira et al. [18] about the capacity of the biosolid to supply $\mathrm{N}$ to banana and also P. These results are important because practically there were no others references about the usage of biosolid as source of plant nutrients in banana orchards. More studies considering fruit quality parameters as well are encouraged.
TABLE 3: Leaf endurance index, N/K relationship in the shoots, plant height, and banana stem diameter due to biosolid or mineral fertilizer application.

\begin{tabular}{|c|c|c|c|c|}
\hline Treatment & LEI, \% & Foliar N/K & $\begin{array}{c}\text { Plant height, } \\
\mathrm{m}\end{array}$ & $\begin{array}{c}\text { Stem } \\
\text { diameter, } \mathrm{m}\end{array}$ \\
\hline \multicolumn{5}{|c|}{2002} \\
\hline Control & $39 \mathrm{ab}$ & $0.95 \mathrm{~b}$ & $2.21 \mathrm{abc}$ & $0.19 \mathrm{ab}$ \\
\hline$T_{L 1}$ & $33 \mathrm{bc}$ & $1.14 \mathrm{a}$ & $2.29 \mathrm{a}$ & $0.21 \mathrm{a}$ \\
\hline$T_{L 2}$ & $32 \mathrm{~cd}$ & $1.20 \mathrm{a}$ & $2.26 \mathrm{ab}$ & $0.20 \mathrm{a}$ \\
\hline$T_{L 3}$ & $26 \mathrm{~d}$ & $1.29 \mathrm{a}$ & $2.26 \mathrm{ab}$ & $0.21 \mathrm{ab}$ \\
\hline$T_{M 1}$ & $39 \mathrm{ab}$ & $1.20 \mathrm{a}$ & $2.16 \mathrm{bc}$ & $0.19 \mathrm{~b}$ \\
\hline$T_{M 2}$ & $40 \mathrm{a}$ & $1.28 \mathrm{a}$ & $2.10 \mathrm{c}$ & $0.19 \mathrm{~b}$ \\
\hline$P_{F 5,4}$ & $<0.0001$ & $<0.0001$ & $<0.0001$ & $<0.0001$ \\
\hline \multicolumn{5}{|c|}{2003} \\
\hline Control & $49 \mathrm{a}$ & $0.74 \mathrm{~b}$ & $2.42 \mathrm{~b}$ & $0.23 \mathrm{ab}$ \\
\hline$T_{L 1}$ & $37 \mathrm{~b}$ & $0.91 \mathrm{a}$ & $2.60 \mathrm{ab}$ & $0.23 \mathrm{ab}$ \\
\hline$T_{L 2}$ & $34 \mathrm{bc}$ & $0.95 \mathrm{a}$ & $2.63 \mathrm{ab}$ & $0.23 \mathrm{ab}$ \\
\hline$T_{L 3}$ & $28 \mathrm{c}$ & $1.02 \mathrm{a}$ & $2.71 \mathrm{a}$ & $0.23 \mathrm{a}$ \\
\hline$T_{M 1}$ & $39 \mathrm{~b}$ & $0.96 \mathrm{a}$ & $2.48 \mathrm{ab}$ & $0.21 \mathrm{~b}$ \\
\hline$T_{M 2}$ & $38 \mathrm{~b}$ & $1.03 \mathrm{a}$ & $2.59 \mathrm{ab}$ & $0.21 \mathrm{ab}$ \\
\hline$P_{F 5,4}$ & $<0.0001$ & $<0.0001$ & 0.023 & 0.012 \\
\hline \multicolumn{5}{|c|}{2004} \\
\hline Control & 63 & $0.74 \mathrm{c}$ & 2.74 & 0.25 \\
\hline$T_{L 1}$ & 61 & $0.92 \mathrm{~b}$ & 2.96 & 0.26 \\
\hline$T_{L 2}$ & 59 & $1.05 \mathrm{ab}$ & 2.95 & 0.26 \\
\hline$T_{L 3}$ & 65 & $1.12 \mathrm{a}$ & 2.92 & 0.26 \\
\hline$T_{M 1}$ & 67 & $1.07 \mathrm{ab}$ & 2.83 & 0.24 \\
\hline$T_{M 2}$ & 62 & $1.10 \mathrm{a}$ & 2.89 & 0.25 \\
\hline$P_{F 5,4}$ & 0.105 & $<0.0001$ & 0.44 & 0.092 \\
\hline
\end{tabular}

LEI: leaf endurance index; $P_{F 5,4}$ : significance of $F$ test for treatment effects at 5 degrees of freedom ( $\mathrm{df}$ ) for treatments and $4 \mathrm{df}$ for error; averages followed by same letters within crop cycles on columns do not differ to Tukey HSD test at $P=0.05$.

Besides being effective, the application of $20 \mathrm{tha}^{-1}$ sludge (dry basis) as source of $\mathrm{N}$ resulted in foliar $\mathrm{N}$ concentrations not statistically different $(P>0.05)$ to that with $400 \mathrm{~kg} \mathrm{ha}^{-1} \mathrm{~N}$ from fertilizer (Figure 3(a)).

Under Brazilian soil and climate conditions different plant species already have shown that the biosolid was efficient to sustain the crop yield at similar levels than the observed with purely mineral fertilizer treated plots $[1,7,27$, 31, 33-36]. The application of biosolid to sugarcane cropped soils as source of $\mathrm{N}$ and $\mathrm{P}$ supplied $100 \%$ of $\mathrm{N}$ and $35 \%$ of the $\mathrm{P}$ requirements on these nutrients [1]. Ryegrass cultivated on soils treated with different types of SS also recovered approximately $36-75 \%$ of the $\mathrm{N}$ and $4-7 \%$ of the $\mathrm{P}$ supplied [7]. This suggests that biosolid is an effective source of $\mathrm{N}$ to Musa spp. plants.

3.3. Leaf Endurance Index. There was no statistical significant difference on leaf endurance index, plant height, and stem diameter within treatments for the third growing season (Table 3). 

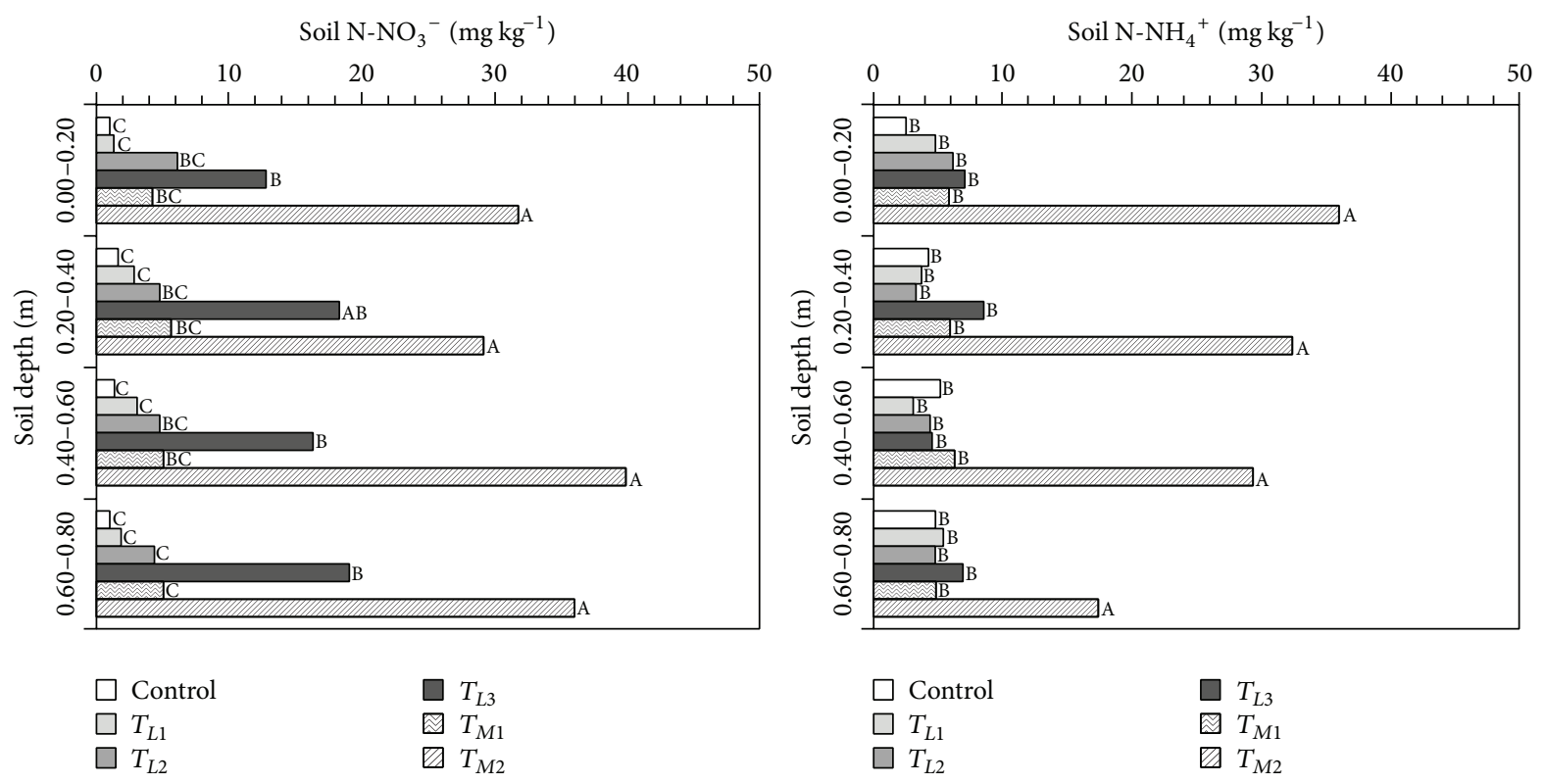

Figure 4: Soil nitrate $\left(\mathrm{N}_{-} \mathrm{NO}_{3}{ }^{-}\right)$and ammonium $\left(\mathrm{N}-\mathrm{NH}_{4}{ }^{+}\right)$as effect of biosolid $\left(T_{L 1}, 100 ; T_{L 2}, 200\right.$; and $T_{L 3}, 400 \mathrm{~kg}$ ha $\left.{ }^{-1} \mathrm{~N}\right)$ and mineral fertilizer $\left(T_{M 1}, 200\right.$ and $\left.T_{M 2}, 400 \mathrm{~kg} \mathrm{ha}^{-1} \mathrm{~N}\right)$. Means followed by same letters, within depths, do not differ statistically by Tukey's test $(P>0.05)$.

Leaf endurance index (LEI) showed to be more sensitive to detect differences between biosolid and mineral fertilizer then height and diameter. For the same $\mathrm{N}$ rate addition, biosolid resulted in a LEI decrease of $6 \%\left(T_{L 2}\right.$ versus $\left.T_{M 1}\right)$ and $4 \%\left(T_{L 3}\right.$ versus $\left.T_{M 2}\right)$ in the first season. The same comparison, made with second season data, showed biosolid depressive effects on LEI of $5 \%\left(T_{L 2}\right.$ versus $\left.T_{M 1}\right)$ and $10 \%\left(T_{L 3}\right.$ versus $T_{M 2}$ ) (Table 3). Although blamed to be an important index to banana cropping management, LEI did not present relationship to fruit yield as the differences between $T_{L 2}$ versus $T_{M 1}$ and $T_{L 3}$ versus $T_{M 2}$ were favorable to biosolid addition in the first growing season (Figure 2). Biological relevance of differences of these magnitudes should be better investigated in future.

In general, the adequate supply of $\mathrm{N}$ tends to maximize banana growth [37]. There are some indications that the maintenance of the foliar $\mathrm{N} / \mathrm{K}$ relationship around 1.5 is need to banana plants keep an adequate number of photosynthetic active leaves. In 2004 foliar $\mathrm{N} / \mathrm{K}$ relationship for $T_{L 3}$ and $T_{M 2}$ were the highest (Table 3 ). Since $\mathrm{K}$ was supplied in a constant rate to all treatments, biosolid should supply $\mathrm{N}$ in order to keep the N/K relationship favorable to plants. This is supported in part, by the higher AgrEff 3 (Figure 2(b)).

3.4. Soil Nitrogen, Organic Carbon, and Available Phosphorus. Soil inorganic N was evaluated only in 2004, three years after the initial application of biosolid and mineral fertilizer. Effects on soil $\mathrm{N}$ content were observed in all soil layers (Figure 4). Only the highest rate of biosolid $\left(T_{L 3}\right)$ and all mineral fertilizer levels increased $\mathrm{N}$-nitrate concentration in comparison to the control (Figure 4).

For the same amount of $\mathrm{N}$, mineral fertilizer $\left(T_{M 2}\right)$ always resulted in higher concentrations of nitrate and ammonium than the biosolid $\left(T_{L 3}\right)$ at the same depth. This is a very common observation as a high percentage of the $\mathrm{N}$ applied in the sludge is bounded in organic matter and has to be mineralized while mineral fertilizers rapidly became available forms.

There was no statistically significant difference between $T_{L 2}$ and $T_{M 1}$ for nitrate and ammonium at all depths. These were the treatments representing the reference values of $\mathrm{N}$ application for banana in Brazil.

These results were in agreement to the related to fruit productivity. Part of the yield variations can be coupled to soil $\mathrm{N}$ because it is one of the most important elements of banana plant nutrition $[2,28,29,31,33,38,39]$. Thus, the more available the $\mathrm{N}$ is, the more the plant grows and produces biomass and fruits. In a different perspective, the application of $400 \mathrm{~kg} \mathrm{ha}^{-1} \mathrm{~N}$ as fertilizer $\left(T_{M 2}\right)$ is more potentially dangerous than the same amount as biosolid $\left(T_{L 3}\right)$ in a single growing season due to the increase of soil N$\mathrm{NO}_{3}$ and $\mathrm{N}-\mathrm{NH}_{4}$ concentration. The most interesting fact is that the application of half of the $\mathrm{N}$ rate as biosolid $\left(T_{L 1}\right)$ had practically no effect on soil inorganic $\mathrm{N}$ accumulation but resulted in the more agronomic effective practice (Figure 2(b)).

The soil organic carbon showed a distinct pattern (Figure 5). In the first year, there was an increment on soil $\mathrm{C}$ content with biosolid application at 0-20 $\mathrm{cm}$ layer (Figure 5).

For the same treatments, in the second year the content of SOC diminished only to rise again in the third growing season. In 2003, even the treatments with mineral fertilizer or the control showed an increase in SOC until the depth of $60 \mathrm{~cm}$ (Figure 5). This was the result of plant growth, mainly root system, and the recycle of biomass from the stems cut after the fruit production.

It was hypothesized that the addition of $\mathrm{N}$ by biosolid stimulated the microorganism to degrade the organic matter 


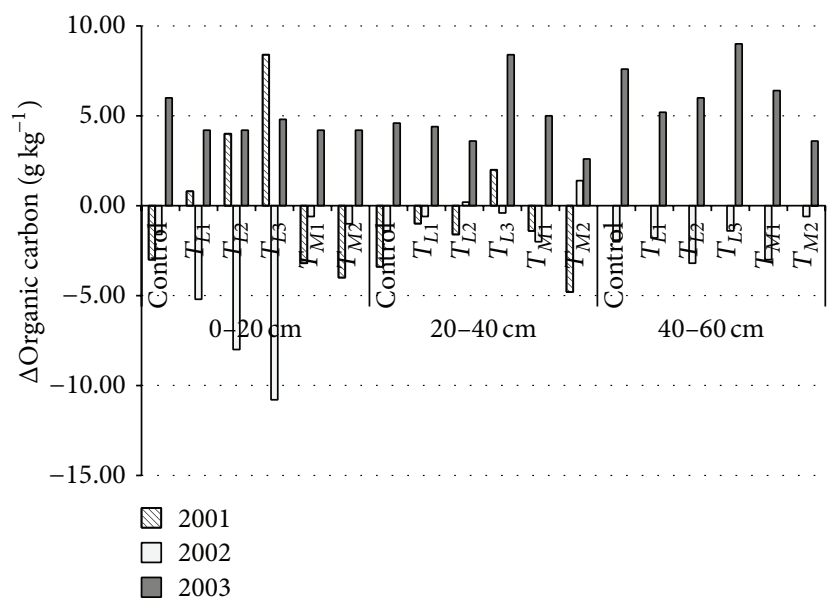

FIGURE 5: Soil organic carbon as effect of biosolid ( $T_{L}$ treatments) and mineral fertilizer ( $T_{M}$ treatments) rates at different depths and years.

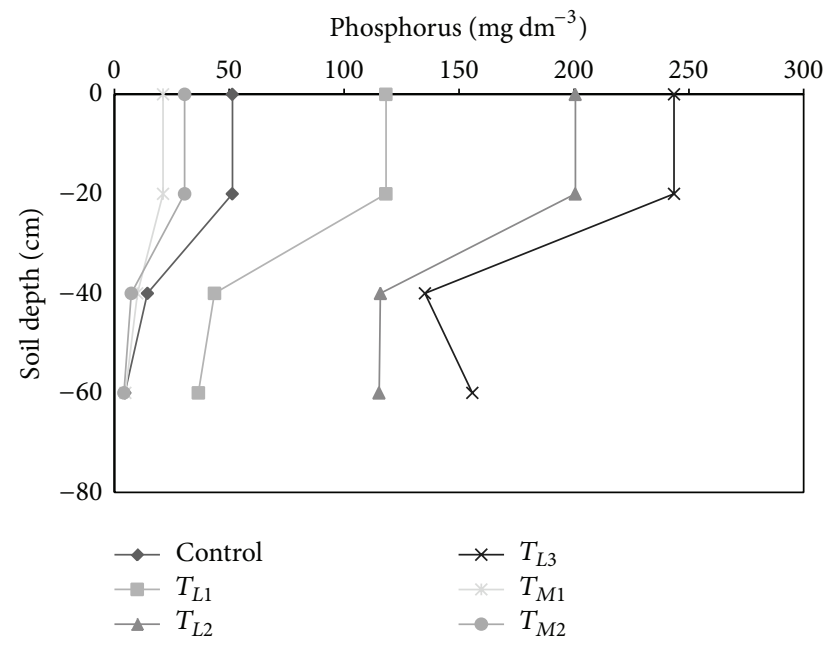

(a)

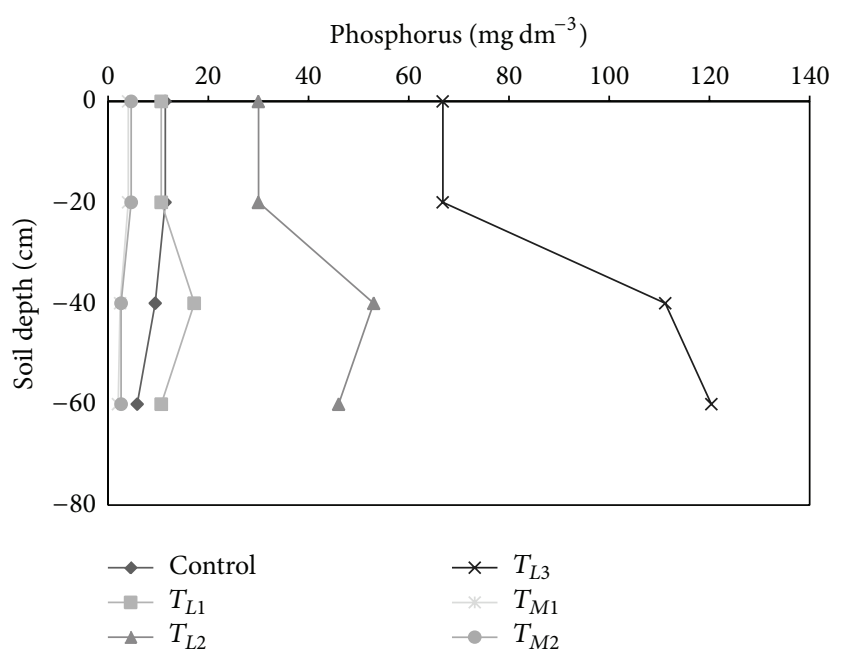

(b)

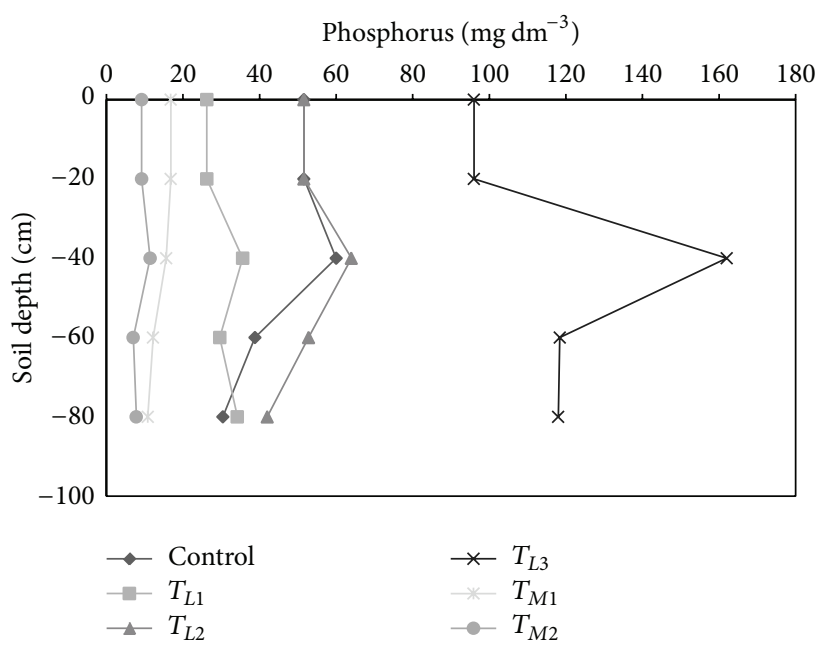

(c)

FIGURE 6: Available phosphorus in different growing seasons and depths as due to the application of biosolid and mineral fertilizer rates in soil cropped with banana. (a) Growing season 2001/2002; (b) growing season 2002/2003; (c) growing season 2003/2004. 
preexisting into the soil in the second growing season. After this a new equilibrium was stablished resulting in the accumulation of new forms of carbon.

The two higher rates of biosolid $\left(T_{L 2}\right.$ and $\left.T_{L 3}\right)$ resulted in the higher concentrations of available phosphorus (Figure 6). For different species, others have reported that the biosolid can supply P $[7,40]$. Chiba et al. [40] reported that for sugarcane, biosolid addition based on $\mathrm{N}$ release can supply approximately $35 \%$ of the $\mathrm{P}$ plant requirement in one growing season.

The soil profile distribution of available $\mathrm{P}$ needs to be more investigated. As can be seen, at $T_{L 2}$ and $T_{L 3}$ more $\mathrm{P}$ were available at deeper layers (Figure 5 ). Brazilian soils are normally rich in iron and aluminum oxides, which result in a high P retention capacity. In growing seasons 2 and 3, biosolid was spread in the soil surface and the mechanism that leads to the increase of $\mathrm{P}$ content at 60 to $80 \mathrm{~cm}$ is still unclear.

\section{Conclusions}

Biosolid is an affordable source of $\mathrm{N}$ and $\mathrm{P}$ for banana plants; biosolid as source of $\mathrm{N}$ to banana plants does not cause depressive effects on biomass production compared to mineral fertilization; the agronomic efficiency index is a reliable tool to describe the response of banana to biosolid application.

\section{Conflict of Interests}

The authors declare that there is no conflict of interests regarding the publication of this paper.

\section{Acknowledgment}

The authors are grateful to the Company of Basic Sanitation of the São Paulo State (SABESP) for the financial aid.

\section{References}

[1] M. K. Chiba, M. E. Mattiazzo, and F. C. Oliveira, "Sugarcane cultivation in a sewage-sludge treated ultisol. II-Soil fertility and plant nutrition," Revista Brasileira de Ciência do Solo, vol. 32, no. 2, pp. 653-662, 2008.

[2] A. Franco, C. H. Abreu Junior, D. Perecin, F. C. Oliveira, A. C. R. Granja, and V. S. Braga, "Sewage sludge as nitrogen and phosphorus source for cane-plant and first ratoon crops," Revista Brasileira de Ciência do Solo, vol. 34, no. 2, pp. 553-561, 2010.

[3] T. A. R. Nogueira, A. Franco, Z. He, V. S. Braga, L. P. Firme, and C. H. Abreu-Junior, "Short-term usage of sewage sludge as organic fertilizer to sugarcane in a tropical soil bears little threat of heavy metal contamination," Journal of Environmental Management, vol. 114, pp. 168-177, 2013.

[4] I. C. de Maria, M. K. Chiba, A. Costa, and R. S. Berton, "Sewage sludge application to agricultural land as soil physical conditioner," Revista Brasileira de Ciência do Solo, vol. 34, no. 3, pp. 967-974, 2010.

[5] I. C. De Maria, M. A. Kocssi, and S. C. F. Dechen, "Agregação do solo em área que recebeu lodo de esgoto," Bragantia, vol. 66, no. 2, pp. 291-298, 2007.
[6] V. P. de Melo, A. N. Beutler, Z. M. de Souza, J. F. Centurion, and W. J. de Melo, "Physical attributes of Oxisols fertilized along five years with biosolids," Pesquisa Agropecuária Brasileira, vol. 39, no. 1, pp. 67-72, 2004.

[7] R. S. Corrêa, "Efficiency of five biosolids to supply nitrogen and phosphorus to ryegrass," Pesquisa Agropecuária Brasileira, vol. 39, no. 11, pp. 1133-1139, 2004.

[8] L. C. Tasso Jr., M. O. Marques, A. Franco et al., "Yield and quality of sugar cane cultivated in sewage sludge, vinasse and mineral fertilization supplied soil," Engenharia Agrícola, vol. 27, no. 1, pp. 276-283, 2007.

[9] T. F. Lobo and H. Grassi Filho, "Níveis de lodo de esgoto na produtividade do girassol," Revista de la Ciencia del Suelo y Nutrición Vegetal, vol. 7, pp. 16-25, 2007.

[10] A. R. M. Anjos and M. E. Mattiazzo, "Heavy metals in corn grown on oxisols continously amended with biosolid," Scientia Agricola, vol. 57, no. 4, pp. 769-776, 2000.

[11] C. A. Andrade, L. F. M. Silva, A. M. M. Pires, and A. R. Coscione, "Mineralization of carbon and nitrogen in soil after successive applications of sewage sludge," Pesquisa Agropecuária Brasileira, vol. 48, no. 5, pp. 536-544, 2013.

[12] Ministério do Meio Ambiente (Brasil), Resolução no. 375 de 26 de agosto de 2006, Conselho Nacional do Meio Ambiente, Brasília, Brazil, 2006.

[13] J. F. Dynia, M. D. de Souza, and R. C. Boeira, "Nitrate leaching in a Typic Haplustox planted with mayze after successive applications of sewage sludge," Pesquisa Agropecuaria Brasileira, vol. 41, no. 5, pp. 855-862, 2006.

[14] F. C. Oliveira, M. E. Mattiazzo, C. R. Marciano, and S. O. Moraes, "Nitrate percolation in a Typic Hapludox amended with urban compost waste or inorganic fertilization," Revista Brasileira de Ciência do Solo, vol. 25, no. 3, pp. 731-741, 2001.

[15] J. J. Chiaradia, M. K. Chiba, C. A. de Andrade, J. B. do Carmo, C. de Oliveira, and A. Lavorenti, " $\mathrm{CO}_{2}, \mathrm{CH}_{4}$ and $\mathrm{N}_{2} \mathrm{O}$ fluxes in an Ultisol treated with sewage sludge and cultivated with castor bean," Revista Brasileira de Ciência do Solo, vol. 33, no. 6, pp. 1863-1870, 2009.

[16] D. I. de Urzedo, M. P. Franco, L. M. Pitombo, and J. B. do Carmo, "Effects of organic and inorganic fertilizers on greenhouse gas (GHG) emissions in tropical forestry," Forest Ecology and Management, vol. 310, pp. 37-44, 2013.

[17] E. Lahav, "Banana nutrition," in Bananas and Plantains, S. Gowen, Ed., World Crop Series, pp. 258-316, Chapman \& Hall, London, UK, 1995.

[18] L. A. J. Teixeira, R. S. Berton, A. R. Coscione, and L. A. Saes, "Biosolids application on banana production: soil chemical properties and plant nutrition," Applied and Environmental Soil Science, vol. 2011, Article ID 238185, 8 pages, 2011.

[19] E. Sakai and I. F. Lepsch, "Levantamento pedológico detalhado da Estação Experimental de Pariquera-Açu," Boletim Tecnico, Instituto Agronômico, Campinas, Brazil, 1984.

[20] B. V. Raij, J. C. de Andrade, and H. C. J. A. Quaggio, Análise química para a avaliação da fertilidade de solos tropicais, Instituto Agronômico de Campinas, 2001.

[21] CETESB, Aplicação de lodos de sistemas de tratamento biológico em áreas agrícolas: critérios de projeto e operação, edited by CETESB, CETESB, São Paulo, Brazil, 1999.

[22] US-EPA, Tested Method for Evaluating Soil Waste: Physical/Chemical Methods (SW846, Method 3051), Edited by USEPA of Solid Waste and Emergency Response, U.S. Government Printing Office, Washington, DC, USA, 1983. 
[23] B. van Raij, H. Cantarella, J. A. Quaggio, and A. M. C. Furlani, Recomendações de Adubação e Calagem para o Estado de São Paulo, Boletim Técnico no. 100, Instituto Agronômico/Fundação IAC, Campinas, Brazil, 2nd edition, 1997.

[24] P. Martin-Prevel, "Bananier," in L'analyse végétale dans le contrôle de l'alimentation des plantes tempérées et tropicales, $\mathrm{P}$. Martin-Prevel, J. Gagnard, and P. Gautier, Eds., pp. 715-751, Tec\&Doc, Paris, France, 1984.

[25] O. C. Bataglia, A. M. C. Furlani, J. P. F. Teixeira, P. R. Furlam, and J. R. Gallo, Métodos de análise quimica de plantas, Boletim Técnico no. 78, Instituto Agronômico, Campinas, Brazil, 1983.

[26] W. C. Lindemann, G. Connell, and N. S. Urquhart, "Previous sludge addition effects on nitrogen mineralization in freshly amended soil," Soil Science Society of America Journal, vol. 52, no. 1, pp. 109-112, 1988.

[27] K. A. Barbarick and J. A. Ippolito, "Nitrogen fertilizer equivalency of sewage biosolids applied to dryland winter wheat," Journal of Environmental Quality, vol. 29, no. 4, pp. 1345-1351, 2000.

[28] W. C. Lindemann and M. Cardenas, "Nitrogen mineralization potential and nitrogen transformations of sludge-amended soil," Soil Science Society of America Journal, vol. 48, no. 5, pp. 1072-1077, 1984.

[29] S. R. Motta and T. Maggiore, "Evaluation of nitrogen management in maize cultivation grows on soil amended with sewage sludge and urea," European Journal of Agronomy, vol. 45, pp. 5967, 2013.

[30] S. O. Petersen, K. Henriksen, G. K. Mortensen et al., "Recycling of sewage sludge and household compost to arable land: fate and effects of organic contaminants, and impact on soil fertility," Soil and Tillage Research, vol. 72, no. 2, pp. 139-152, 2003.

[31] S. O. Petersen, J. Petersen, and G. H. Rubæk, "Dynamics and plant uptake of nitrogen and phosphorus in soil amended with sewage sludge," Applied Soil Ecology, vol. 24, no. 2, pp. 187-195, 2003.

[32] P. R. Warman and W. C. Termeer, "Evaluation of sewage sludge, septic waste and sludge compost applications to corn and forage: yields and N, P and K content of crops and soils," Bioresource Technology, vol. 96, no. 8, pp. 955-961, 2005.

[33] C. A. de Andrade, L. F. Mendonça Silva, A. M. Moreno Pires, and A. R. Coscione, "Mineralization of carbon and nitrogen in soil after successive applications of sewage sludge," Pesquisa Agropecuária Brasileira, vol. 48, no. 5, pp. 536-544, 2013.

[34] M. K. Chiba, M. E. Mattiazzo, and F. C. Oliveira, "Sugarcane cultivation in a sewage-sludge treated ultisol. I-soil nitrogen availability and plant yield," Revista Brasileira de Ciência do Solo, vol. 32, no. 2, pp. 643-652, 2008.

[35] J. M. Fernández, C. Plaza, J. C. García-Gil, and A. Polo, "Biochemical properties and barley yield in a semiarid Mediterranean soil amended with two kinds of sewage sludge," Applied Soil Ecology, vol. 42, no. 1, pp. 18-24, 2009.

[36] U. Song and E. J. Lee, "Environmental and economical assessment of sewage sludge compost application on soil and plants in a landfill," Resources, Conservation and Recycling, vol. 54, no. 12, pp. 1109-1116, 2010.

[37] E. Lahav and D. W. Turner, Banana Nutrition, IPI-Bulletin no. 7, International Potash Institute, Bern, Switzerland, 1983.

[38] H. L. Frost and L. H. Ketchum Jr., "Trace metal concentration in durum wheat from application of sewage sludge and commercial fertilizer," Advances in Environmental Research, vol. 4, no. 4, pp. 347-355, 2000.
[39] M. Zaman, M. Matsushima, S. X. Chang et al., "Nitrogen mineralization, $\mathrm{N}_{2} \mathrm{O}$ production and soil microbiological properties as affected by long-term applications of sewage sludge composts," Biology and Fertility of Soils, vol. 40, no. 2, pp. 101109, 2004.

[40] M. K. Chiba, M. E. Mattiazzo, and F. C. Oliveira, "Rendimento de cana-de-açúcar cultivada em Argissolo, utilizando lodo de esgoto como fonte de fósforo," Acta Scientiarum. Agronomy, vol. 31, no. 3, pp. 495-501, 2009. 

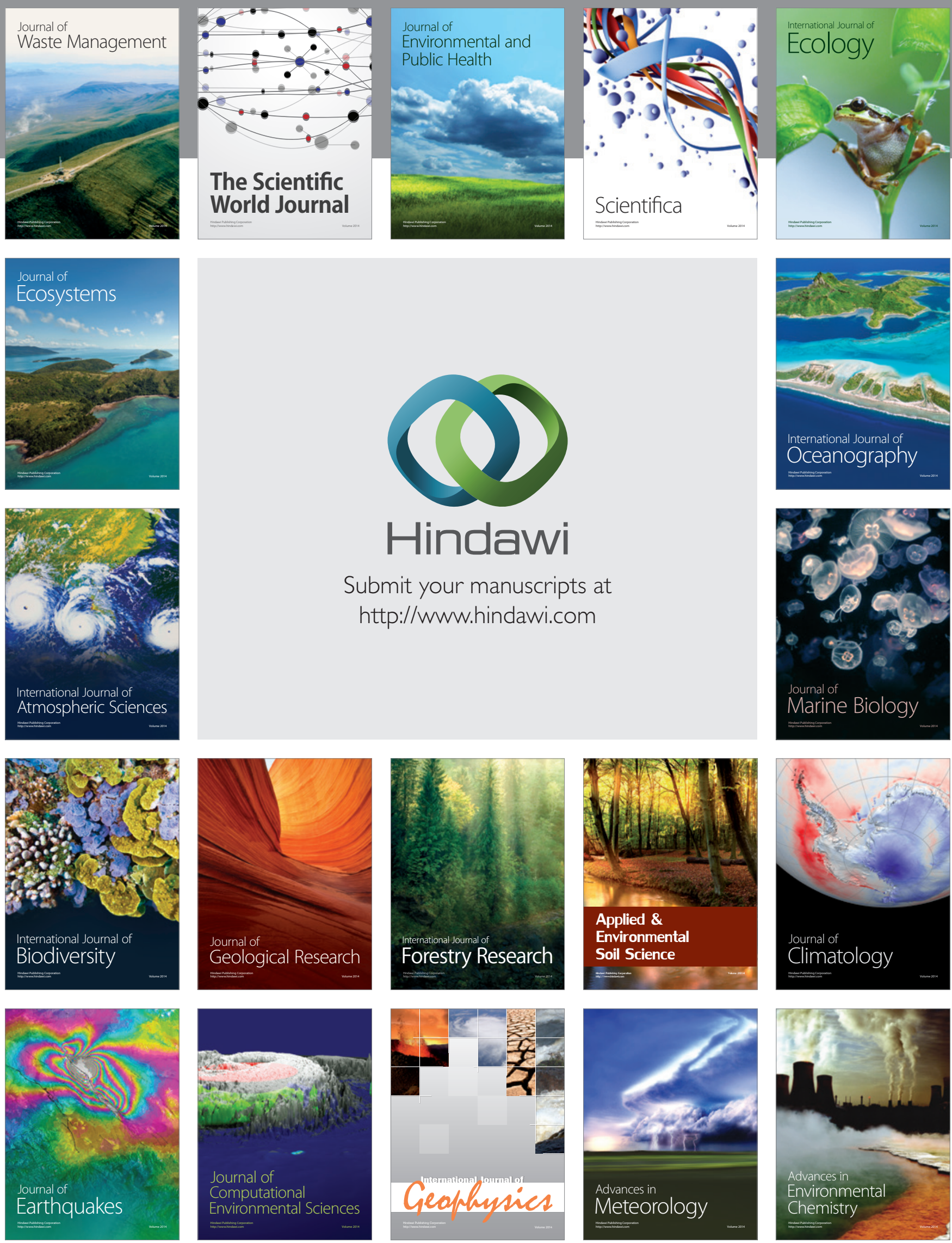